\title{
An iron-regulated LysR-type element mediates antimicrobial peptide resistance and virulence in Yersinia pseudotuberculosis

\begin{abstract}
Correspondence
Michaël Marceau

michael.marceau@ibl.fr
\end{abstract} \\ Received 12 December 2008 \\ Revised 19 March 2009 \\ Accepted 9 April 2009

\author{
Sonia Arafah, ${ }^{1,2,3,4}$ Marie-Laure Rosso, ${ }^{1,2,3,4} †$ Linda Rehaume, ${ }^{5}$ \\ Robert E. W. Hancock, ${ }^{5}$ Michel Simonet ${ }^{1,2,3,4}$ and Michaël Marceau 1,2,3,4 \\ ${ }^{1}$ Inserm U801, F-59019 Lille, France \\ ${ }^{2}$ Université Lille Nord de France, F-59000 Lille, France \\ ${ }^{3}$ Institut Pasteur de Lille, F-59019 Lille, France \\ ${ }^{4}$ CHULille, F-59000 Lille, France \\ ${ }^{5}$ Department of Microbiology and Immunology, Center for Microbial Diseases and Immunity Research, \\ Lower Mall Research Station, University of British Columbia, Vancouver, BC V6T 1Z4, Canada
}

\begin{abstract}
During the course of its infection of the mammalian digestive tract, the entero-invasive, Gramnegative bacterium Yersinia pseudotuberculosis must overcome various hostile living conditions (notably, iron starvation and the presence of antimicrobial compounds produced in situ). We have previously reported that in vitro bacterial growth during iron deprivation raises resistance to the antimicrobial peptide polymyxin B; here, we show that this phenotype is mediated by a chromosomal gene (YPTB0333) encoding a transcriptional regulator from the LysR family. We determined that the product of YPTB0333 is a pleiotropic regulator which controls (in addition to its own expression) genes encoding the Yfe iron-uptake system and polymyxin B resistance. Lastly, by using a mouse model of oral infection, we demonstrated that YPTВ033З is required for colonization of Peyer's patches and mesenteric lymph nodes by $Y$. pseudotuberculosis.
\end{abstract}

\section{INTRODUCTION}

Iron is an essential nutrient for almost all micro-organisms, since it is present in the active site of a number of key enzymes involved in essential metabolic pathways (such as the tricarboxylic acid cycle, the respiratory chain and DNA synthesis) (Andrews et al., 2003). In mammals, limiting access to iron is a critical line of host defence against bacterial pathogens and is achieved by the deployment of specific proteins which bind ferric iron (the usual state of iron under aerobic, neutral-pH conditions) with high affinity (Hentze et al., 2004). Hence, in order to replicate in vivo, a bacterial pathogen needs to take up ferric ions from the host's protein complexes. This is performed by ironacquisition systems, the most common of which are the siderophores (Ratledge \& Dover, 2000). After bacterial

tPresent address: Unité de Prévention et Thérapies Moléculaires des Maladies Humaines, Centre National de Référence de la coqueluche et autres bordetelloses, 28 rue du Dr Roux, F-75724 Paris cedex 15, France.

Abbreviation: MFS, major facilitator superfamily.

A supplementary table, listing putative additional YPTB0333-regulated genes, and a supplementary figure, showing promoter analysis of the YPTB0331 and YPTB0333 genes, are available with the online version of this paper. internalization and entry into the cytosol, insoluble ferric cations are reduced to soluble ferrous cations (Vartivarian \& Cowart, 1999). Additionally, iron starvation signals to a pathogen that it has entered the mammalian host and triggers production of virulence factors (such as exotoxins) that allow microbial tissue colonization (Calderwood \& Mekalanos, 1987; Leong \& Murphy, 1985; Lory, 1986). Gene expression induced by iron limitation is often controlled by global regulators, including the Fur ferric uptake regulator (Bagg \& Neilands, 1987).

The Gram-negative bacterium Yersinia pseudotuberculosis is a pathogen of the digestive tract of animals (including humans), and causes ileitis and mesenteric adenitis after ingestion of contaminated food or water. During the course of infection in the gut, this entero-invasive microorganism must not only overcome iron starvation but also resist antimicrobial peptides termed defensins (cryptdins in mice) (Hancock \& Diamond, 2000) produced in large amounts in the crypts of the intestinal lumen by epithelial cells, i.e. Paneth cells and enterocytes (Ayabe et al., 2000; Bevins, 2004). After binding to LPS on the bacterial surface through electrostatic interactions, antimicrobial peptides permeabilize the bacterial membranes and potentially lead to cell death (Shai, 2002; Yeaman \& Yount, 2003). It has been demonstrated in different studies that in order to 
circumvent the microbicidal activity of these host compounds, bacteria have developed a range of strategies that are reminiscent of those involved in antibiotic resistance (Nizet, 2006). One stratagem involves producing bacterial proteases that degrade antimicrobial peptides (Stumpe et al., 1998). Another incorporates positively charged groups into the lipid $\mathrm{A}$, reducing the net anionic charge of the bacterial envelope and thus lowering the affinity of the latter for antimicrobial peptides (Groisman et al., 1997; Gunn et al., 1998, 2000). Additional resistance mechanisms involve preventing the antimicrobial peptides from accessing their target via extracellular trapping by secretory proteins (Jin et al., 2004) or actively pumping the peptides back across the cytoplasmic membrane (Shafer et al., 1998). Hence, bacterial determinants that support antimicrobial peptide resistance (the expression of which is frequently induced by environmental cues) can be viewed as virulence factors per se (Garcia Vescovi et al., 1996; Wösten et al., 2000).

In a previous study (Marceau et al., 2004), we observed an increase in Y. pseudotuberculosis resistance to polymyxin B (the benchmark cationic antimicrobial peptide) when bacteria were grown under iron-starvation conditions: to the best of our knowledge, such a phenotype had not been reported for any bacteria. We have now identified the genetic determinant of inducible resistance to polymyxin B in $Y$. pseudotuberculosis and demonstrate that one of the genes involved contributes to bacterial virulence and promotes intestinal colonization by the enteropathogen.

\section{METHODS}

Bacterial strains and growth conditions. The main characteristics of the plasmids and bacterial strains used in this study are listed in Tables 1 and 2. Escherichia coli, Y. pseudotuberculosis and Yersinia enterocolitica strains were grown aerobically in Luria-Bertani (LB) broth or on agar, at $37{ }^{\circ} \mathrm{C}$ for the first-mentioned species and at $28{ }^{\circ} \mathrm{C}$ for the last two. Ampicillin $\left(50 \mu \mathrm{g} \mathrm{ml}{ }^{-1}\right)$, kanamycin $(50 \mu \mathrm{g}$ $\left.\mathrm{ml}^{-1}\right)$, chloramphenicol $\left(30 \mu \mathrm{g} \mathrm{ml}^{-1}\right)$, irgasan $\left(4 \mu \mathrm{g} \mathrm{ml}^{-1}\right)$ and sucrose $(10 \%)$ were added to media for bacterial selection when necessary. IPTG $(1 \mathrm{mM})$ and X-Gal $\left(200 \mu \mathrm{g} \mathrm{ml}^{-1}\right)$ were used for blue/white colony screening.

Reagents. The iron chelator $2,2^{\prime}$-dipyridyl and polymyxin B were purchased from Sigma. Dansyl-polymyxin B was obtained from Molecular Probes.

Molecular biology techniques. Standard procedures were used for genomic DNA extraction, small-scale plasmid preparation, endonuclease digestion, DNA ligation, agarose gel electrophoresis, elution of DNA fragments and E. coli transformation (Sambrook \& Russell, 2001). Large-scale plasmid DNA preparations were purified on

Table 1. Strains used in this study

Ap, ampicillin; Km, kanamycin; Cm, chloramphenicol; s, susceptible; r, resistant.

\begin{tabular}{|c|c|c|}
\hline Strain & Relevant characteristics & Reference or source \\
\hline $\mathrm{DH} 5 \alpha$ & $\begin{array}{l}\mathrm{F}^{-} \text {Ф80dlacZDM15 } \Delta(\text { lacZYA-argF }) U 169 \text { recA1 endA1 hsdR17 }\left(\mathrm{r}_{\mathrm{k}}^{-} \mathrm{m}_{\mathrm{k}}^{-}\right) \\
\text {supE44 } \lambda^{-} \text {thi-1 gyrA relA1; host for DNA cloning }\end{array}$ & Invitrogen \\
\hline EC100 & $\begin{array}{l}\mathrm{F}^{-} \text {mcrA } \Delta(\text { mrr-hsdRMS-mcrBC) } \Phi 80 \text { dlacZ } \Delta \mathrm{M} 15 \Delta \text { lacX74 recA1 endA1 araD139 } \\
\Delta(\text { ara,leu }) 7697 \text { galU galK } l^{-} \text {rpsL nupG relA1; host for DNA cloning }\end{array}$ & Epicentre Biotechnologies \\
\hline BL21-DE3 & $\begin{array}{l}\mathrm{F}^{-} \text {ompT hsdS }\left(\mathrm{r}^{-} \mathrm{m}^{-}\right) \text {gal dcm (DE3); host for efficient recombinant protein } \\
\text { expression }\end{array}$ & Invitrogen \\
\hline SY327 $\lambda$ pir & $\begin{array}{l}\Delta(\text { lac pro }) \operatorname{argE}(\mathrm{Am}) \text { recA rif nalA } \lambda \text { pir, host for replication of suicide plasmids } \\
\text { pCVD442 and derivatives }\end{array}$ & Miller \& Mekalanos (1988) \\
\hline SM10 $\lambda$ pir & $\begin{array}{l}\text { thi thr leu sup tonA lacY recA:: RP4-2Tc:: MuKm } \lambda \text { pir, host for replication of } \\
\text { suicide plasmids pCVD442 and derivatives }\end{array}$ & Simon et al. (1983) \\
\hline \multicolumn{3}{|c|}{ Y. pseudotuberculosis strains } \\
\hline IP32777 & Wild-type strain, harbouring the virulence plasmid pYV; $\mathrm{Ap}^{\mathrm{s}}, \mathrm{Km}^{\mathrm{s}}$ & Sebbane et al. (2001) \\
\hline \multicolumn{3}{|c|}{ Y. enterocolitica strains } \\
\hline IP383 & O9 serogroup wild-type strain; $\mathrm{Ap}^{\mathrm{r}}, \mathrm{Cm}^{\mathrm{s}}$ & \\
\hline 5.1 & IP383 complemented with plasmid pSA5.1 & This work \\
\hline 5.1 .1 & IP383 complemented with plasmid pSA5.1.1 & This work \\
\hline 5.1 .2 & IP383 complemented with plasmid pSA5.1.2 & This work \\
\hline 5.1 .3 & IP383 complemented with plasmid pSA5.1.3 & This work \\
\hline 5.1 .4 & IP383 complemented with plasmid pSA5.1.4 & This work \\
\hline
\end{tabular}


Table 2. Plasmids used in this study

$\mathrm{Ap}^{\mathrm{r}}, \mathrm{Km}^{\mathrm{r}}, \mathrm{Cm}^{\mathrm{r}}$, resistance to ampicillin, kanamycin and chloramphenicol, respectively. $\Omega$, in vitro insertion; $\mathrm{F}$, forward; $\mathrm{R}$, reverse.

\begin{tabular}{|c|c|c|}
\hline Plasmid & Relevant characteristics & Reference or source \\
\hline pUC18 & Cloning vector; $A p^{r}$ & Appligene \\
\hline pCVD442 & Suicide vector containing the counter-selectable marker $s a c B$; $\mathrm{Ap}^{\mathrm{r}}$ & $\begin{array}{l}\text { Donnenberg \& Kaper } \\
\text { (1991) }\end{array}$ \\
\hline pUC4K & Source of aminoglycoside phosphotransferase $a p h A-1 a$ gene; $\mathrm{Km}^{\mathrm{r}}$ & Amersham Pharmacia \\
\hline pET24a $(+)$ & Expression vector; $\mathrm{Km}^{\mathrm{r}}$ & Novagen \\
\hline pSA & pACYC184 derivative with $l a c Z^{\prime}$ and the multiple cloning site from pUC18; $\mathrm{Cm}^{\mathrm{r}}$ & Flamez et al. (2008) \\
\hline pSA5.1 & $\begin{array}{l}\text { pSA } \Omega 7923 \text { bp (Y. pseudotuberculosis IP32777 chromosomal fragment located at position } \\
392816 \text { to } 400738 \text { ) }\end{array}$ & This work \\
\hline pSA5.1.1 & pSA $\Omega 2709$ bp (fragment generated by BamHI and BglII digestion of pSA5.1) & This work \\
\hline pSA5.1.2 & $\begin{array}{l}\text { pSA } \Omega 4633 \text { bp (fragment generated by } N d e I \text { digestion of pSA5.1 and self-ligation of the } \\
\text { remaining plasmid) }\end{array}$ & This work \\
\hline pSA5.1.3 & pSA $\Omega 4664$ bp (fragment generated by PstI digestion of pSA5.1) & This work \\
\hline pSA5.1.4 & $\begin{array}{l}\text { pSA } \Omega 6296 \text { bp (fragment generated by } N c o \text { I digestion of } 5.1 \text { region and self-ligation of } \\
\text { the remaining plasmid) }\end{array}$ & This work \\
\hline pCVD0331-0332-Aph & $\begin{array}{l}\text { pCVD442 } \Omega 2022 \mathrm{bp}(1245 \mathrm{bp} \text { aphA-1a inserted at position } 560 \text { in a } 777 \mathrm{bp} \text { SacI/SacI PCR } \\
\text { fragment generated with primer sets F4/R4 and F5/R5 and derived from the YPTB0331 and } \\
\text { YPTB0332 genes of Y. pseudotuberculosis) }\end{array}$ & This work \\
\hline pCVD0333-Aph & $\begin{array}{l}\text { pCVD } 442 \Omega 2190 \text { bp (1245 bp aphA-1a inserted at position } 345 \text { in a } 945 \text { bp SacI/SacI PCR } \\
\text { fragment generated with primer set F1/R1 and derived from the YPTB0333 gene of } Y \text {. } \\
\text { pseudotuberculosis) }\end{array}$ & This work \\
\hline pCVD0331-0333-Aph & $\begin{array}{l}\text { pCVD } 442 \Omega 2047 \text { bp (1245 bp aphA-1a inserted at position } 394 \text { in a SacI/SacI PCR fragment } \\
\text { generated with primer sets F21/R21and F22/R22 and derived from the YPTB0331 and } \\
\text { YPTB0333 genes of Y. pseudotuberculosis) }\end{array}$ & \\
\hline pCVD0333 & $\begin{array}{l}\text { pCVD442 } \Omega 1269 \text { bp (Sacl/SacI PCR fragment generated with primer set F2/R2 and derived } \\
\text { from pSA5.1) }\end{array}$ & This work \\
\hline pЕТ-ҮРТВ0333 & $\begin{array}{l}\text { pET24a }(+) \Omega 980 \mathrm{bp}(\mathrm{Ndel} / \mathrm{XhoI} \text { PCR fragment generated with F3/R3 and derived from } \\
\text { pSA5.1) }\end{array}$ & This work \\
\hline
\end{tabular}

Qiagen columns. Recombinant plasmid DNA was introduced into $Y$. pseudotuberculosis and $Y$. enterocolitica by mating or electroporation (Conchas \& Carniel, 1990). Southern blots were performed according to standard procedures. The ECL direct nucleic acid labelling and detection system (Amersham Biosciences) was used for nucleic acid hybridization. DNA was sequenced with the dideoxy-chain-termination method using the ABI PRISM Dichlororhodamine Dye Terminator Sequencing kit with AmpliTaq DNA polymerase FS (Perkin-Elmer). The nucleotide sequences obtained were analysed with Sequencher v4.2.2 software.

Oligonucleotide primers (Table 3) were custom-synthesized (Eurogentec and MWG Biotech) for the PCR generation of DNA fragments used in cloning or probing. PCR amplification was performed as described previously (Sebbane et al., 2001) with AmpliTaq Gold polymerase (Perkin-Elmer Applied Biosystems) and PCR products were purified using a Qiaquick PCR purification kit (Qiagen).

Total RNA was extracted with the RNeasy kit (Qiagen). mRNAs were reverse-transcribed into cDNA from $1 \mu \mathrm{g}$ nucleic acid by using specific primers and Transcriptor reverse transcriptase, according to the manufacturer's instructions (Roche). The resulting cDNAs were amplified using the primer sets described in Table 3 and the Power SYBR Green PCR master mix. Amplimers were detected on a Prism 7300 detection system (Applied Biosystems). The 16S rrn gene was used for normalization. On completion of PCR amplification, a DNA melting curve analysis was performed to confirm the presence of a single amplicon. Relative mRNA levels $\left(2^{-\Delta \Delta \mathrm{Ct}}\right)$ were determined by comparing (i) the PCR cycle thresholds $(\mathrm{Ct})$ for the gene of interest and 16S rrn $(\Delta \mathrm{C})$, and (ii) $\mathrm{Ct}$ values in the absence and presence of iron $(\Delta \Delta \mathrm{C})$.

Gene mutagenesis and complementation. pUC18 plasmid derivatives containing an inactivated copy of the microbial gene of interest were generated as follows: briefly, each construct was obtained by fusing the upstream and downstream regions of the PCR-amplified target gene with the $5^{\prime}$ and $3^{\prime}$ ends of the kanamycinresistance gene aphA-Ia, respectively. DNA inserts were then subcloned into the suicide vector pCVD442 (Donnenberg \& Kaper,

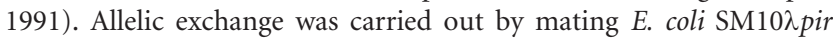
with $Y$. pseudotuberculosis. Yersinia transconjugants were screened on LB medium supplemented with irgasan. Concomitantly, ampicillin and kanamycin were also added in order to select the first recombination event. To select for the second recombination event, the presence of pCVD442 (which bears the levane sucrase-encoding gene $s a c B$ ) was counter-selected on LB agar plus $10 \%$ sucrose. Ampicillin-susceptible and kanamycin-resistant clones were isolated, and the expected mutations were checked by Southern blot analysis with appropriate DNA probes. Mutants were cis-complemented with wild-type genes borne on the suicide plasmid pCVD442, with merodiploids that resulted from homologous recombination being selected on LB agar plus ampicillin.

Genomic library construction. Partially digested Sau3AI fragments (5-10 kb) from the Y. pseudotuberculosis IP32777 genome were inserted into the BamHI restriction site of pSA, a low-copy-number derivative of pACYC184; this avoids the cloning of genes that are 
Table 3. Yersinia-specific oligonucleotide primers used in this study

F, Forward; R, reverse.

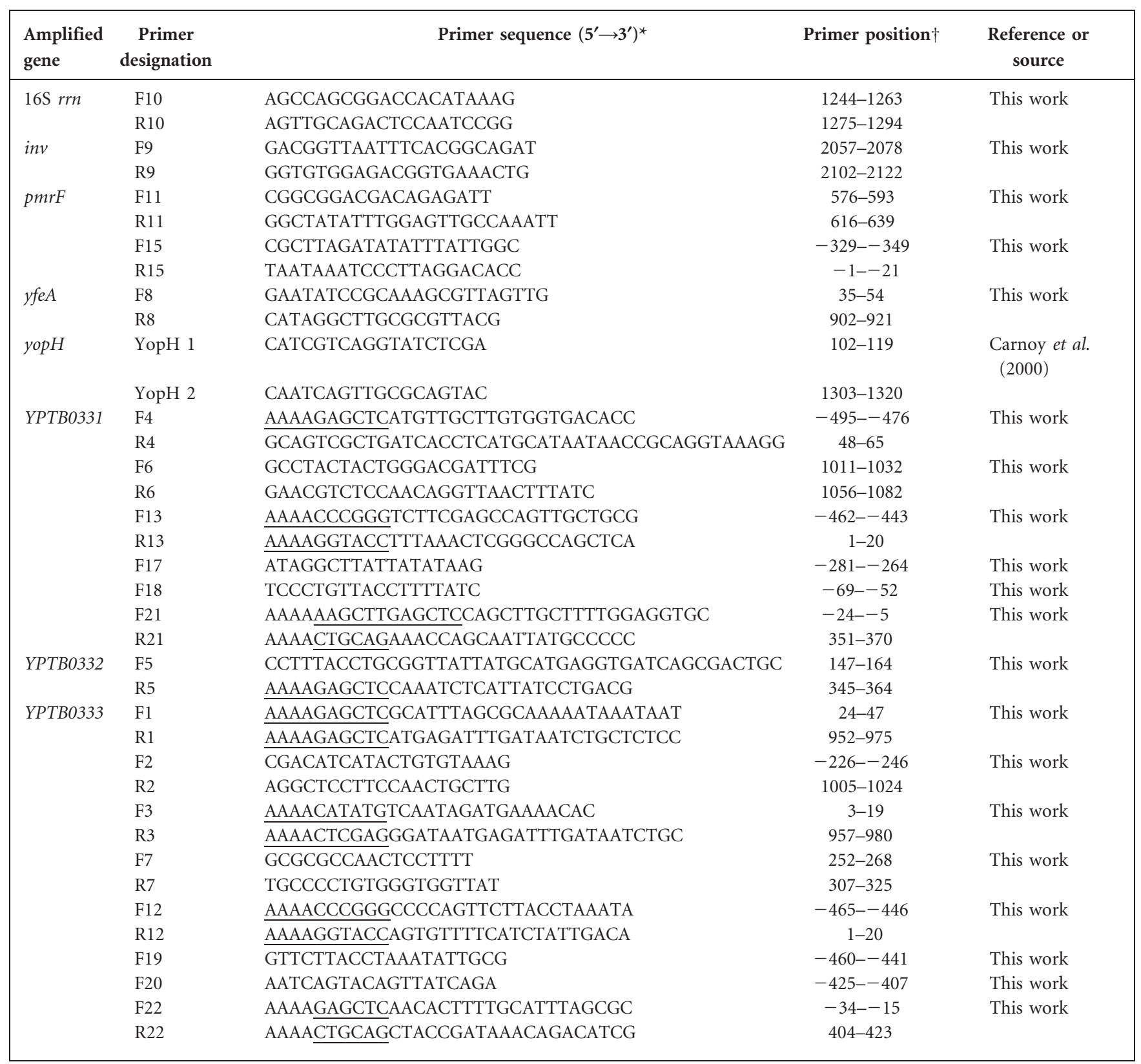

${ }^{\star}$ Targeted gene-specific sequences are in upper-case type and additional nucleotides at the $5^{\prime}$ end recognized by a restriction endonuclease (HindIII for F21; KpnI for R12 and R13; NdeI for F3; PstI for R3, R21 and R22; SacI for F1, R1, F4, F21 and F22; SmaI for F12 and F13) are underlined. $\dagger$ Relative to the start codon.

potentially deleterious to bacteria when present in a high copy number. Thereafter, E. coli EC100 was transformed with recombinant plasmids and the transformants were screened on IPTG-X-Gal agar. Plasmids were extracted from white colonies and introduced (by electroporation) into $Y$. enterocolitica IP383. Recombinant bacteria were selected on LB agar with chloramphenicol.

Polymyxin B activity. The bactericidal assay was performed with Yersinia cells from cultures in LB broth (which naturally contains iron) at $28{ }^{\circ} \mathrm{C}$ for $16-18 \mathrm{~h}\left(\mathrm{OD}_{620} 0.3\right)$, followed by an additional $3 \mathrm{~h}$ incubation at $37^{\circ} \mathrm{C}$ in LB broth with or without $300 \mu \mathrm{M}$ of the iron chelator 2,2'-dipyridyl. First, $10 \mu \mathrm{l}$ of serial dilutions in distilled water of polymyxin B $\left(50 \mathrm{mg} \mathrm{ml}^{-1}\right.$ in sterile distilled water, $0.1 \% \mathrm{BSA}$, $0.01 \%$ acetic acid) was distributed into microtitre plate wells. Thereafter, $100 \mu \mathrm{l}$ Yersinia cell suspension was added to each well (final bacterial concentration $2.5 \times 10^{6}$ c.f.u. $\mathrm{ml}^{-1}$ ). As a control, bacterial suspensions were concomitantly added to wells containing $100 \mu \mathrm{l}$ incubation medium lacking polymyxin B. Microtitre plates were shaken gently and then incubated at $37^{\circ} \mathrm{C}$ for $2 \mathrm{~h}$. To assess Yersinia viability, $50 \mu \mathrm{l}$ mixture from each well was serially diluted in 
sterile distilled water. Diluates were plated on LB and incubated at $28{ }^{\circ} \mathrm{C}$ for $48-72 \mathrm{~h}$. Bacterial survival was defined as the ratio of the number of viable bacteria after a $2 \mathrm{~h}$ contact with polymyxin $\mathrm{B}$ to the number of viable bacteria in the absence of the antimicrobial peptide.

The polymyxin-binding assay was performed by using dansylpolymyxin B (Moore et al., 1986). Bacteria were grown at $37^{\circ} \mathrm{C}$ for $3 \mathrm{~h}$. After centrifugation, the cell pellets were suspended in sterile water and $2 \times 10^{6}$ Yersinia were incubated for 15 min at $37{ }^{\circ} \mathrm{C}$ with $1 \mu \mathrm{g}$ dansyl-polymyxin B. Bacteria were examined with a Zeiss microscope equipped with suitable filters for fluorescence emission at $485 \mathrm{~nm}$. Fluorescence intensity was quantified using ImageJ software.

Measurement of antimicrobial peptide MICs. MICs of reported antimicrobial peptides (Friedrich et al., 1999, 2000; Gudmundsson et al., 1996; Miyata et al., 1989; Selsted et al., 1992) were determined using a standard microtitre dilution assay in Mueller-Hinton (MH) medium. Briefly, cells were grown overnight at $28{ }^{\circ} \mathrm{C}$ in $\mathrm{MH}$ broth and diluted in the same medium. Twofold serial dilutions (in $0.01 \%$ acetic acid $/ 0.2 \%$ BSA) of the peptides were added to the microtitre plates and then bacterial suspensions were added (final inoculum $1-5 \times 10^{5}$ c.f.u. $\mathrm{ml}^{-1}$ ). Plates were incubated at $28{ }^{\circ} \mathrm{C}$ for $24 \mathrm{~h}$ and the MIC was determined as the lowest peptide concentration that inhibited bacterial growth.

Purification of His-tagged recombinant proteins. The recombinant BL21-DE3 E. coli strain harbouring pET-YPTB0333 was grown in $11 \mathrm{LB}$ medium supplemented with kanamycin $\left(50 \mu \mathrm{g} \mathrm{ml} \mathrm{m}^{-1}\right)$. When the $\mathrm{OD}_{600}$ reached 0.8 , expression of the gene encoding the recombinant protein was induced with $1 \mathrm{mM}$ IPTG for $1 \mathrm{~h}$. The cells were harvested by centrifugation and then resuspended in $5 \mathrm{ml}$ lysis buffer $\left(300 \mathrm{mM} \mathrm{NaCl}, 50 \mathrm{mM} \mathrm{Na} \mathrm{HPO}_{4}, 5 \mathrm{mM}\right.$ imidazole, $\mathrm{pH}$ 8) per gram fresh weight. Cells were lysed using a French press at a pressure of 1000 p.s.i. $(6900 \mathrm{kPa})$ The lysate was clarified by centrifugation at $10000 \mathrm{~g}$ for $20 \mathrm{~min}$. The supernatant was loaded on a Hi-Trap HP chelating column (GE Healthcare). The column was washed first with standard lysis buffer (containing $5 \mathrm{mM}$ imidazole) and then with lysis buffer containing $20-50 \mathrm{mM}$ imidazole. Elution was performed with lysis buffer containing $200 \mathrm{mM}$ imidazole. The collected fractions were analysed by SDS-PAGE, using a $10 \%$ polyacrylamide gel and Coomassie Blue staining, and by Western blot analysis with an anti-polyhistidine antibody (H1029, Sigma). The purified YPTB0333 protein was dialysed against the DNA-binding buffer [10 mM Tris/HCl, pH 7.5, $1 \mathrm{mM}$ EDTA, $5 \mathrm{mM}$ DTT, $5 \%$ (v/v) glycerol, $10 \mathrm{mM} \mathrm{NaCl}, 1 \mathrm{mM} \mathrm{MgCl}_{2}, 100 \mathrm{mg} \mathrm{BSA} \mathrm{ml}^{-1}$ ].

Electrophoretic mobility shift assay. Purified PCR-generated DNA fragments were incubated for $20 \mathrm{~min}$ at room temperature with purified protein in DNA-binding buffer in a $20 \mu \mathrm{l}$ volume (Heroven \& Dersch, 2006). Next, the reaction mixture was loaded onto an $8 \%$ polyacrylamide gel and subjected to electrophoresis. The DNA was revealed by ethidium bromide staining.

Mouse infection. Experiments with 6-week-old, female BALB/c mice (purchased from Charles River) were performed in an accredited establishment (the Institut Pasteur de Lille) in accordance with current European legislation and guidelines (number 86/609/EEC) and following approval by the local ethics committee (file number 04-10003). For each experimental murine infection with Y.pseudotuberculosis, the presence of the pYV virulence plasmid in mutant and wild-type strains was confirmed by PCR on total bacterial DNA using YopH 1 and YopH 2 primers (which correspond to sequences within yopH, a gene located on virulence plasmid pYV) (Carnoy et al., 2000). Bacterial inocula were prepared from overnight cultures in LB broth at $28{ }^{\circ} \mathrm{C}$. The cultures were centrifuged and the bacterial pellets were washed once and suspended in distilled water or PBS (Invitrogen). Mice were challenged either intragastrically $(0.2 \mathrm{ml}$ bacterial suspension in sterile distilled water) using a gastric tube or intravenously ( $0.3 \mathrm{ml}$ bacterial suspension in sterile PBS). Mice were fasted for $18 \mathrm{~h}$ prior to gastric inoculation. Infected animals were kept in positive-pressure cabinets throughout the experiment. Mortality was monitored twice daily for up to 21 days post-challenge. The survival kinetics and survival rates for mutant- and wild-type-infected mice were compared statistically using the log-rank test. In order to assess bacterial colonization of the digestive tract, five infected animals were killed at day 3 post-inoculation and Yersinia were counted by spreading dilutions of Peyer's patches and mesenteric lymph node homogenates on LB agar. The c.f.u. numbers in lymphoid tissues of mutant- and wild-type-infected animals were compared using the Mann-Whitney statistical test.

\section{RESULTS}

\section{Polymyxin B resistance is induced by iron starvation in $Y$. pseudotuberculosis but not in $Y$. enterocolitica}

We had previously observed that when exponentially growing Y. pseudotuberculosis IP32777 was inoculated into growth medium supplemented with the iron chelators desferral or 2,2-dipyridyl, the resistance of the bacterium to polymyxin B increased about 20-fold (Marceau et al., 2004). In the present study, we assessed whether this phenotype could also be observed in the closely related enteropathogenic species Y. enterocolitica (Bottone, 1997) under iron availability limitation conditions. Since this micro-organism is more susceptible to polymyxin B than Y. pseudotuberculosis (Bengoechea et al., 1998), we used lower concentrations of the antibiotic in our in vitro assay. As shown in Fig. 1(a), the polymyxin B resistance of $Y$. enterocolitica IP383 did not change according to whether iron was complexed or not in the culture medium. We thus hypothesized that $Y$. pseudotuberculosis, but not $Y$. enterocolitica, possesses a polymyxin B-resistance mechanism involving one or more genes whose expression is induced by iron starvation.

To identify these genes, we complemented Y. enterocolitica IP383 with a random genomic library from Y. pseudotuberculosis IP32777 in low-copy-number plasmid pSA, a pACYC184 derivative that did not change the Y. enterocolitica polymyxin B-resistance phenotype (results not shown). The resulting recombinant bacteria were assessed for polymyxin B susceptibility in the presence and absence of iron. Of the approximately 10000 transformants tested, one (designated Ye5.1) displayed a 50-fold increase in polymyxin B resistance in iron-depleted growth medium. Furthermore, the intrinsic resistance level of the transformant was around 1000-fold higher than that of the $Y$. enterocolitica wild-type strain (Fig. 1b).

\section{Adjacent $Y$. pseudotuberculosis chromosomal genes YPTB0331-0332 and YPTB0333 confer inducible polymyxin $B$ resistance in $Y$. enterocolitica}

Plasmid 5.1 was extracted from Y. enterocolitica and the $5^{\prime}$ and $3^{\prime}$ ends of the $Y$. pseudotuberculosis DNA insert were 


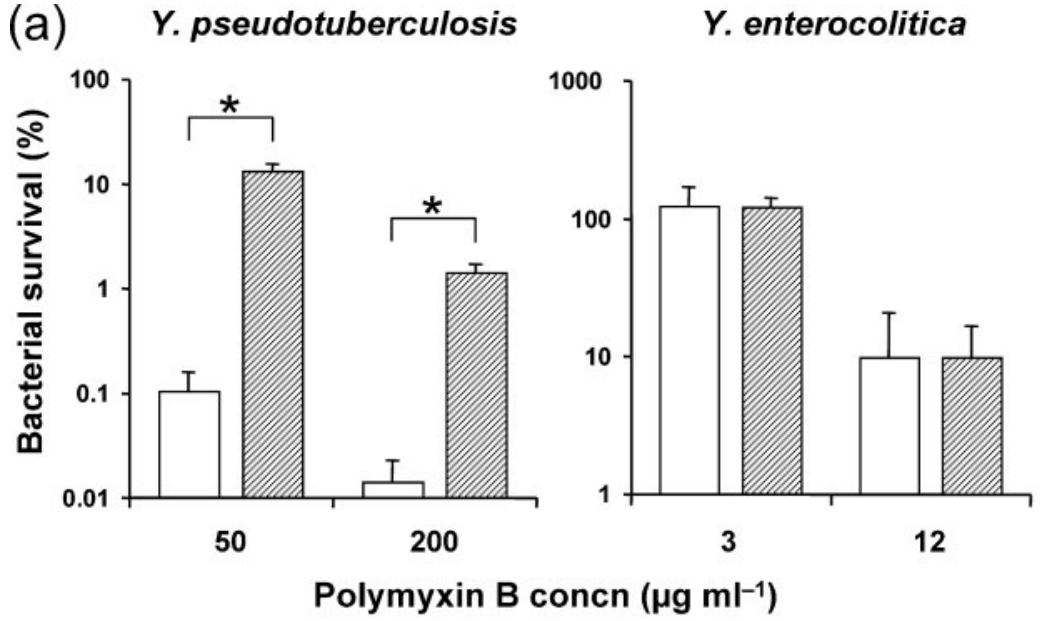

(b) Y. enterocolitica (pSA)
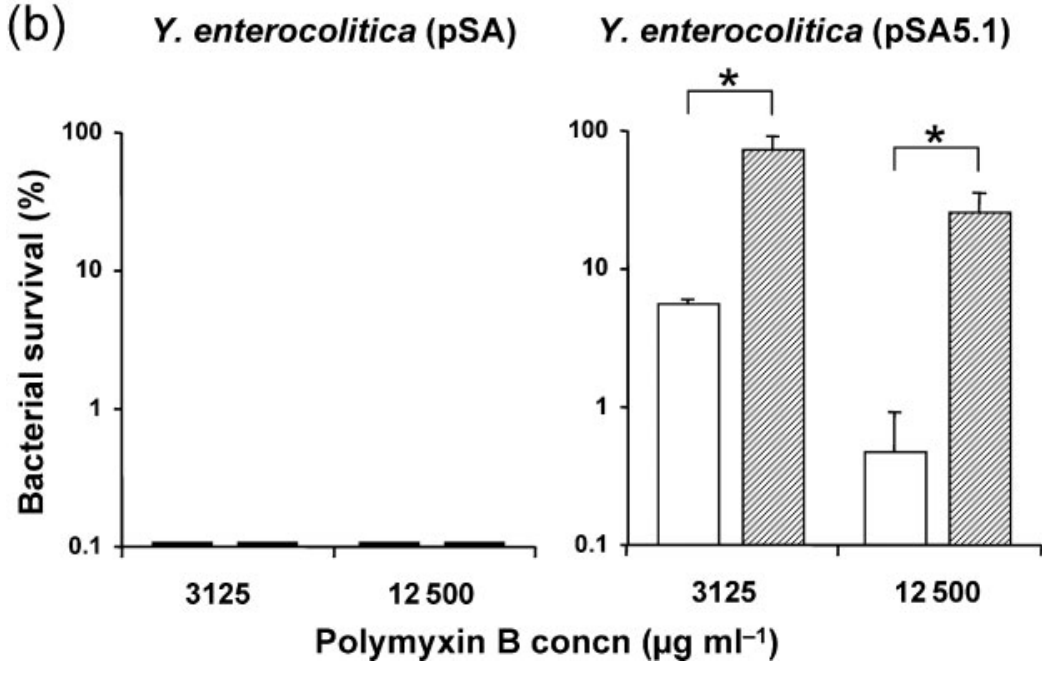

Fig. 1. Polymyxin B resistance of iron-starved $Y$. pseudotuberculosis and $Y$. enterocolitica. (a) Y. pseudotuberculosis IP32777 and $Y$. enterocolitica IP383 were incubated at $37{ }^{\circ} \mathrm{C}$ under normal (white bars) or iron-restricted (hatched bars) conditions, with various amounts of polymyxin B. Bacterial survival was assessed after a $2 \mathrm{~h}$ incubation period. Each bar represents the mean value $(+S D)$ of three independent experiments. Y. pseudotuberculosis and $Y$. enterocolitica survival rates in the presence of polymyxin $B$ were compared using the Mann-Whitney test. Asterisks indicate significant differences $(P<0.05)$. (b) Recombinant $Y$. enterocolitica strains harbouring pSA or pSA5.1 were incubated at $37{ }^{\circ} \mathrm{C}$ under normal (white bars) or iron-restricted (hatched bars) conditions with 3125 or $12500 \mu \mathrm{g}$ polymyxin $\mathrm{B} \mathrm{ml}^{-1}$. Bacterial survival was assessed after a $2 \mathrm{~h}$ incubation period. Each bar represents the mean value (+SD) of three independent experiments. Survival rates in the presence of polymyxin B were compared using a Mann-Whitney test. Asterisks indicate significant differences $(P<0.05)$. sequenced. Nucleotide sequence alignment of the insert termini with the whole genome of $Y$. pseudotuberculosis strain IP32953 (Chain et al., 2004) revealed that the Y. pseudotuberculosis 5.1 region was a $7.5 \mathrm{~kb}$ fragment located on the bacterial chromosome from nucleotide position 392841 through to 400738 . On the basis of restriction endonuclease analyses, we determined that the fragment is organized in the same way as in strain IP2353 and comprises nine genes (YPTB0327 to YPTB0335), with those at each extremity being truncated (Fig. 2). YPTB0327 to YPTB0330 belong to a polycistronic unit (composed of 18 other genes that were not included in the 5.1 insert) encoding the chromosomal type III secretion system Ysa (Chain et al., 2004; Foultier et al., 2002). YPTB0331 and YPTB0332 overlap and are probably co-transcribed, as suggested by promoter prediction analysis. YPTB0333 is adjacent to YPTB0331 and YPTB0332 but is transcribed in the opposite direction.

In order to define which of these genes are required for inducible polymyxin $\mathrm{B}$ resistance under iron-starvation conditions, we subcloned the 5.1 region into plasmid pSA and phenotyped the five resulting $Y$. enterocolitica subclones. Plasmid pSA5.1.3 (including YPTB0331-0332-0333) was necessary and sufficient for iron-induced resistance to polymyxin B to the same extent as the entire 5.1 region (Fig. 2). In contrast, neither plasmid pSA5.1.1 (containing YPTB0331-332) nor pSA5.1.2 (harbouring YPTB0333) conferred such a phenotype. YPTB0331 encodes a putative transporter component with 10 transmembrane segments and shares homology with efflux pump proteins of the major facilitator superfamily (MFS) (Pao et al., 1998). The product of YPTB0332 belongs to a protein family of unknown function, whereas that of YPTB0333 displays similarities with transcriptional regulators from the LysR family (Maddocks \& Oyston, 2008; Schell, 1993).

\section{Y. enterocolitica harbouring YPTB0331-0333 does not bind polymyxin B}

One of the main bacterial targets of polymyxin B is LPS (Schindler \& Osborn, 1979; Vaara \& Viljanen, 1985), and so we decided to compare polymyxin B binding to wildtype $Y$. enterocolitica and $Y$. enterocolitica harbouring plasmid pSA5.1. This was achieved by fluorescence microscopy analysis of microbial cells incubated with dansyl-polymyxin B, a polymyxin B derivative that 


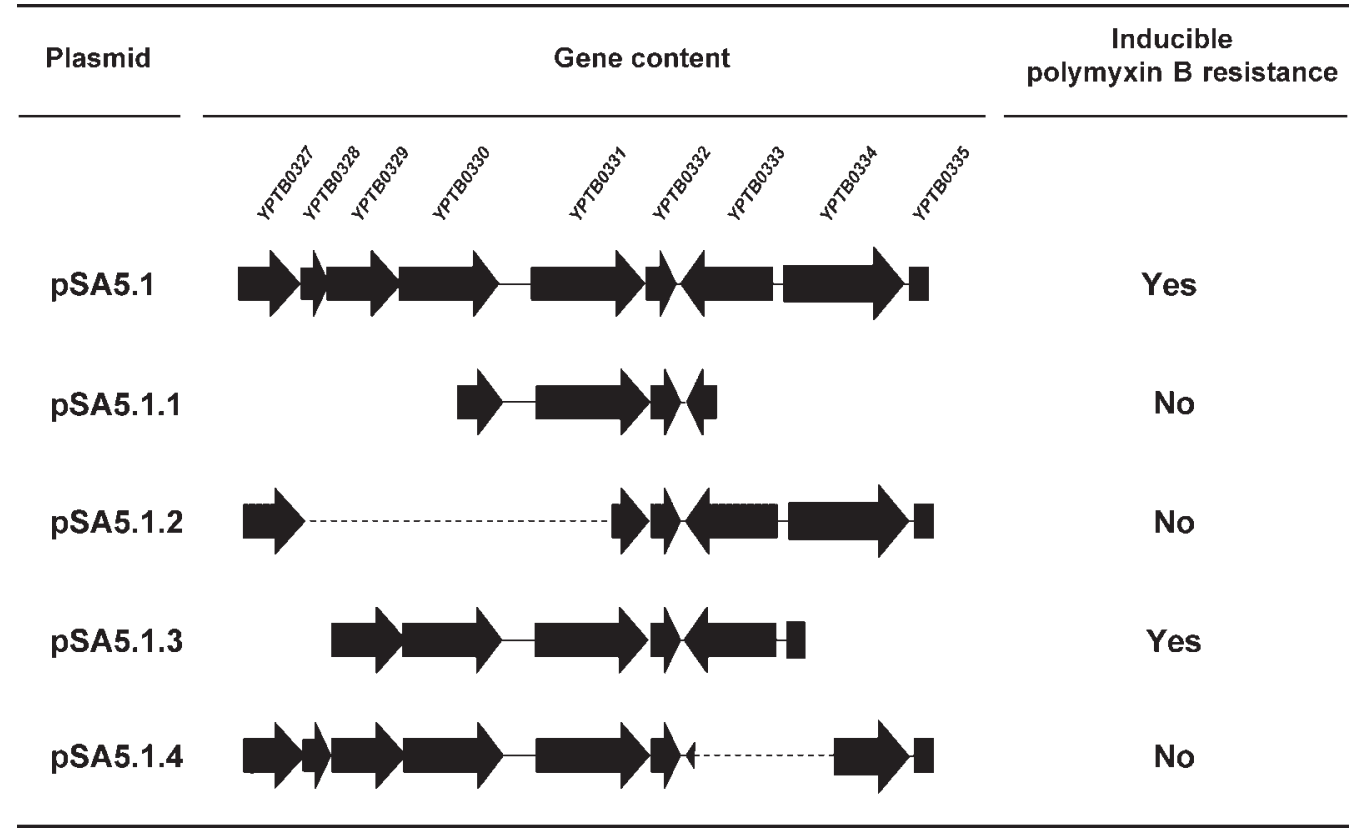

Fig. 2. Polymyxin B resistance of $Y$. enterocolitica 5.1 subclones under iron-limitation conditions. The genetic organization of the $7.5 \mathrm{~kb}$ Y. pseudotuberculosis region 5.1 is shown and the inducible polymyxin resistance conferred by the chromosomal segment is mapped.

demonstrates an increase in (green) fluorescence after it binds to LPS but is weakly fluorescent when free in solution. As depicted in Fig. 3, wild-type cells fluoresced after incubation with dansyl-polymyxin B, whereas recombinant 5.1 cells did not. From this experiment, we conclude that YPTB0331, YPTB0332 and YPTB0333 may modify the Yersinia surface and thus decrease the binding of polymyxin B.

\section{Only the YPTB0333 knockout is associated with impaired polymyxin $B$ resistance in Y. pseudotuberculosis}

To confirm the involvement of YPTB0331-0332 and 0333 in $Y$. pseudotuberculosis polymyxin B resistance, two mutants were engineered from strain IP32777 via (i) deletion of both YPTB0331 and YPTB0332 and (ii) disruption of YPTB0333. Their differential susceptibility to polymyxin B (presented in Fig. 4) indicated that only YPTB0333 inactivation leads to impaired bacterial resistance to this compound. cis-Complementation of the YPTB0333 mutant (resulting from chromosomal integration of pCVD442, bearing YPTB0333) restored the wildtype phenotype and thus ruled out a polar effect of a YPTB0333 mutation. Secondly, a triple mutant (in which YPTB0331-0332 and YPTB0333 had been inactivated) displayed the same polymyxin B-resistance phenotype as the YРTB0333 single mutant strain (data not shown). Interestingly, antimicrobial resistance in the $Y$. pseudotuberculosis YPTB0333 mutant was still inducible by iron starvation, suggesting that other iron-inducible resistance gene(s) may exist in this species. Thus, our results indicate that in contrast to YPTB0331-0332, YPTB0333 plays a significant role in resistance to polymyxin $\mathrm{B}$ in $Y$. pseudotuberculosis. Nevertheless, the three genes YPTB0331-0332-0333 are all required for polymyxin B resistance in $Y$. enterocolitica.

\section{YPTB0333 regulates the YPTB0331-0332 operon and its own expression in an iron-dependent manner}

We assumed that expression of YPTB0331-0332 and YPTB0333 was triggered by iron starvation, and therefore used quantitative RT-PCR (qRT-PCR) to evaluate gene transcript levels in $Y$. pseudotuberculosis under these conditions. Concomitantly, we studied two transcription controls: (i) the iron transporter-encoding gene yfeA, which is induced by iron restriction (Bearden et al., 1998), and (ii) the invasin-encoding gene inv, which is ironindependent (Heroven et al., 2007). As shown in Fig. 5(a), the YPTB0331-0332 and YPTB0333 genes were upregulated when $Y$. pseudotuberculosis was grown in the presence of the iron chelator 2,2'-dipyridyl. We suspected that YPTB0333 mediates transcription of the upstream operon in iron-starved $Y$. pseudotuberculosis, since it is contiguous with the YPTB0331-0332 operon (but has opposite polarity) and encodes a product that shares motifs with transcriptional regulators from the LysR family. The strong observed reduction in YPTB0331-0332 expression after 
(a)
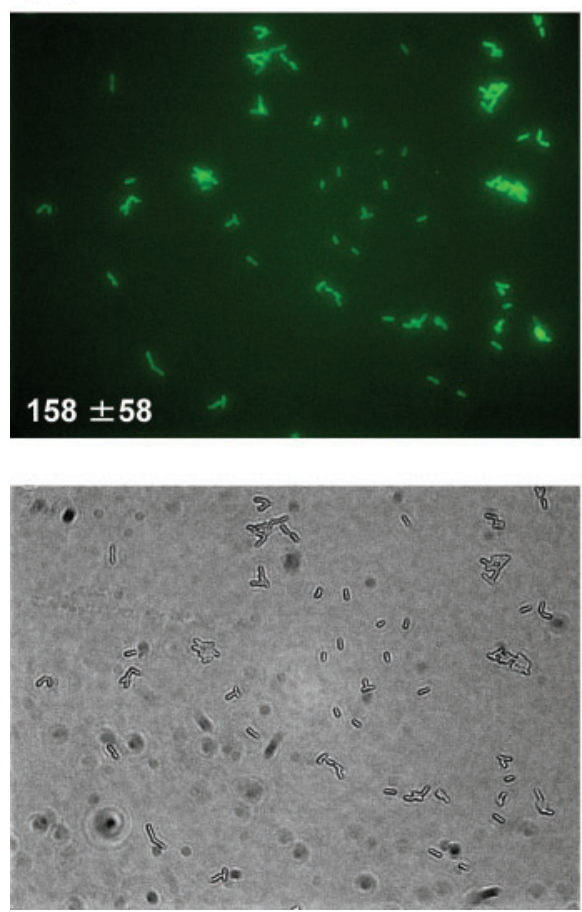

(b)
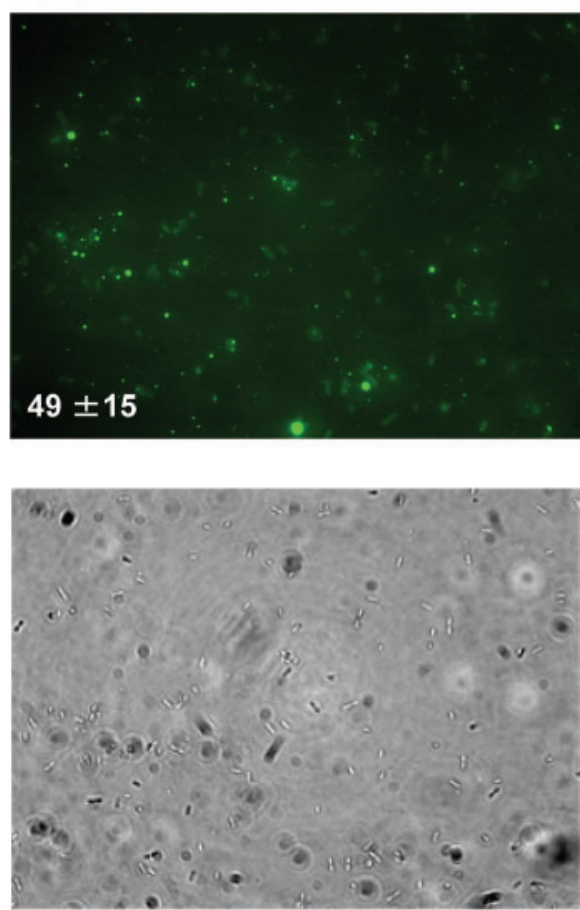

Fig. 3. Dansyl-polymyxin B binding to $Y$. enterocolitica complemented (or not) with the 5.1 region from $Y$. pseudotuberculosis. Bacteria grown in iron-depleted LB medium were incubated for $15 \mathrm{~min}$ with $1 \mu \mathrm{g}$ dansyl-polymyxin B and examined by fluorescence microscopy. The figure shows representative photographs of $Y$. enterocolitica bearing (a) pSA and (b) pSA5.1 (i.e. including the $Y$. pseudotuberculosis 5.1 locus) exposed to UV light (upper panels) or not (lower panels). Green dots are assumed to correspond to dansyl-polymyxin B aggregates. Mean fluorescence intensity values ( \pm SD) from three independent experiments are indicated in the upper panels.

inactivation of YPTB0333 (Fig. 5b) was consistent with this hypothesis. Furthermore, it was demonstrated that upregulation of $y f e A$ under iron-starvation conditions was diminished in the YPTB0333 mutant. Transcriptional regulatory activity of the YPTB0333 product was definitively proven by demonstrating its binding to the
YPTB0331-0332 promoter (Fig. 5c). Since LysR-type regulators autoregulate their expression (Schell, 1993), we monitored the ability of YPTB0333 to bind to the YPTB0333 promoter. As shown in Fig. 5(c) by using an electrophoretic mobility shift assay, YPTB0333 recognized this promoter in a dose-dependent manner.

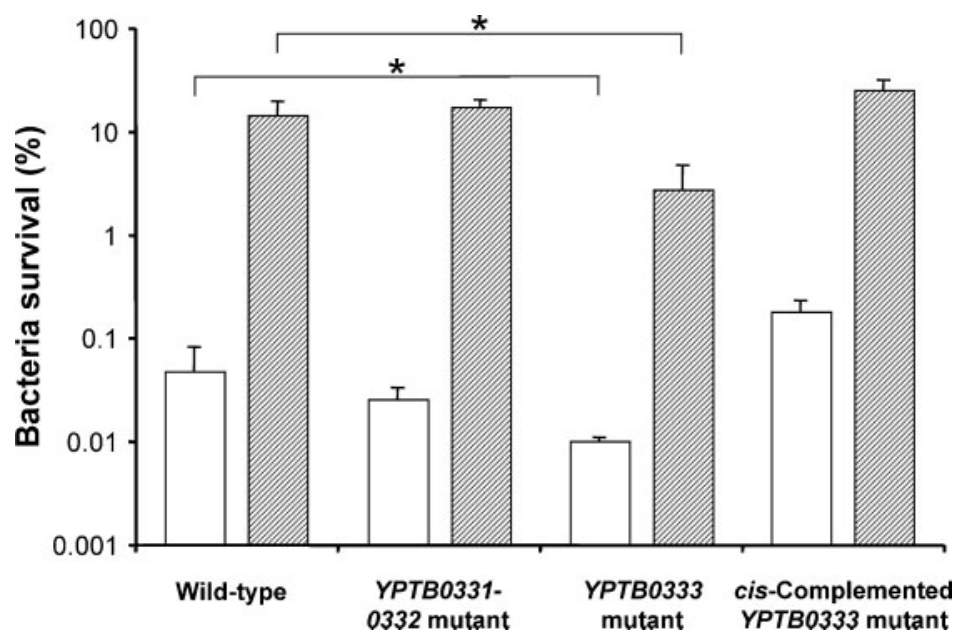

Fig. 4. Polymyxin B susceptibility of $Y P T В 0333$ and YPTВ0331-0332 Y. pseudotuberculosis mutants. Yersinia were incubated at $37{ }^{\circ} \mathrm{C}$ in normal (white bars) or iron-starved (shaded bars) Roswell Park Memorial Institute (RPMI) medium with $50 \mu \mathrm{g}$ polymyxin $\mathrm{B} \mathrm{ml}^{-1}$. Bacterial survival was assessed $2 \mathrm{~h}$ later. Each bar represents the mean value $(+S D)$ of three independent experiments. Wild-type and mutant survival after polymyxin B treatment was compared using the Mann-Whitney test. $P$ values $<0.05$ are indicated by asterisks. 

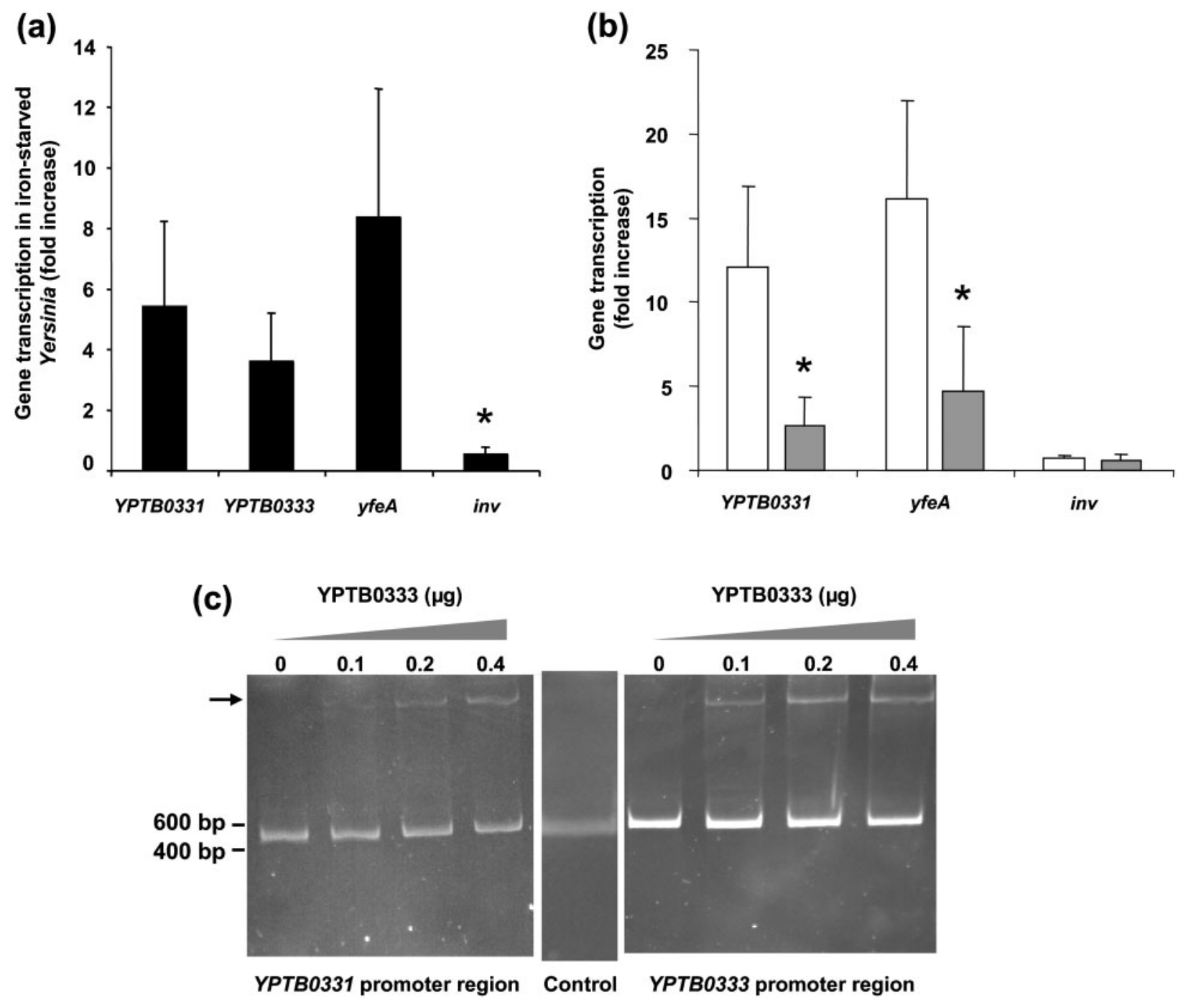

Fig. 5. Regulation of YPTB0331-0332 and YPTB0333 genes. (a) YPTB0331 and YPTB0333 expression in iron-starved wildtype $Y$. pseudotuberculosis. Total RNA from wild-type $Y$. pseudotuberculosis grown in standard or iron-depleted LB broth was extracted and reverse-transcribed into cDNA specific for YPTB0331, YPTB0333, yfe $A$ and inv genes using the reverse primers (R6, R7, R8 and R9, respectively) described in Table 3. cDNAs were then amplified by real-time PCR with primer sets F6/R6, F7/ R7, F8/R8 and F9/R9. Data were normalized against the $16 \mathrm{~S}$ rrn values obtained with primers F10 and R10. Results are presented as the fold increase in gene expression under iron-starvation conditions versus standard conditions. Each bar represents the mean value (+SD) of three independent experiments. Gene expression was compared with that of $y f e A$ using the Mann-Whitney test, and asterisks indicate significant differences $(P<0.05)$. (b) YPTB0331, yfe $A$ and inv expression in iron-starved wild-type and YPTВ0333-deficient $Y$. pseudotuberculosis. Total RNA from wild-type (white bars) and YPTB0333-deficient (grey bars) $Y$. pseudotuberculosis cultured in standard or iron-depleted LB broth was extracted and reverse-transcribed to cDNA specific for YPTB0331, yfeA and inv with primers R6, R8 and R9, respectively. Next, the cDNA was amplified by real-time PCR with primer sets F6/R6, F8/R8 and F9/R9. The data were normalized against the respective $16 S$ rrn values obtained with primers F10 and R10. Results are presented as the fold increase in gene expression under iron-restriction conditions versus standard conditions. Each bar represents the mean value ( $+\mathrm{SD}$ ) of three independent experiments. A Mann-Whitney test was used to compare the two strains in terms of YPTB0331 and $y f e A$ expression, and asterisks indicate a significant difference $(P<0.05)$. (c) YPTB0333 binding to the promoter region of the $Y$. pseudotuberculosis YPTB0331 and YPTB0333 genes. Fragments (500 bp) encompassing the putative YPTB0331 and YPTВ0333 promoters (see Supplementary Fig. S1) were PCR-generated with primers F12/R12 and F13/R13. The figure shows electrophoretic mobility of the ethidium bromide-stained 500 bp fragment alone or mixed with $0.1,0.2 \mathrm{or} 0.4 \mu \mathrm{g}$ purified YPTB0333. The arrow indicates the highest-molecular-mass YPTB0333-DNA complex. No binding of YPTB0333 to an irrelevant DNA fragment (a 400 bp internal fragment from $Y$. pseudotuberculosis m/tB) was detected (control) and an excess of the irrelevant DNA fragment did not inhibit YPTВ0333 binding to the YPTВ0331 and YPTВ0333 promoters (results not shown). Additionally, a YPTВ0333-free protein fraction obtained for the purification procedure of the recombinant protein was unable to alter the mobility of the DNA fragment encompassing the YPTB0333 promoter (not shown). As shown, YPTB0333 bound specifically to the DNA segment encompassing the putative promoter of the YPTB0331 and YPTB0333 genes. 


\section{YPTB0333 binds to the promoter region of the pmrF operon}

One common bacterial surface modification governing polymyxin B resistance in Gram-negative bacteria (including Yersinia) is L-4-aminoarabinose substitution of LPS, which contributes to a reduction in the net negative charge of lipid A. This substitution is mediated by a seven-gene polycistronic unit ( $p m r H F I J K L M$, the pmrF operon) (Gunn et al., 1998). Therefore, we hypothesized that decreased binding of polymyxin B to the cell envelope of ironrestricted Yersinia was associated with $p m r F$ upregulation. Indeed, in $Y$. enterocolitica trans-complemented with YPTB0331-0332-0333 (i.e. strain Ye5.1, in which dansylpolymyxin binding was impaired, see Fig. 3), we observed that transcription of the $p m r F$ gene of the operon was sevenfold greater than in Y. enterocolitica bearing the empty vector pSA (data not shown). Conversely, expression of this gene was diminished by nearly threefold in $Y$. pseudotuberculosis after inactivation of YPTB0333. Although this reduction was not statistically significant [most likely because $p m r F$ transcription has been shown to be regulated by other means, such as the two-component system regulator PhoP (Marceau et al., 2004)], YPTB0333 is nevertheless likely to regulate the $p m r F$ operon by binding upstream of pmrH (Fig. 6).

\section{YPTB0333 mutation decreases Y. pseudotuberculosis pathogenicity}

In the digestive tract of its host, the enteropathogen $Y$. pseudotuberculosis encounters both iron-limiting conditions and high quantities of antimicrobial peptides. Therefore, we assessed whether inactivation of the abovementioned polymyxin B-resistance genes could alter $Y$. pseudotuberculosis virulence in vivo. Using a murine model of oral infection, we found that inactivation of YPTB0333, but not of YPTB0331-0332, significantly reduced bacterialinduced lethality in mice (Fig. 7a). The mechanism was thought to be due to an increased susceptibility to killing by cationic antimicrobial peptides, as the YPTB0333 mutant demonstrated increased susceptibility to a range of such peptides (Table 4). However, as previously reported (Marceau et al., 2004), the Y. pseudotuberculosis pmrF operon is dispensable for mouse infection. In contrast, the YPTB0333 mutant (as well as the YPTB0331-0332 mutant) was as virulent as the parent strain when administered
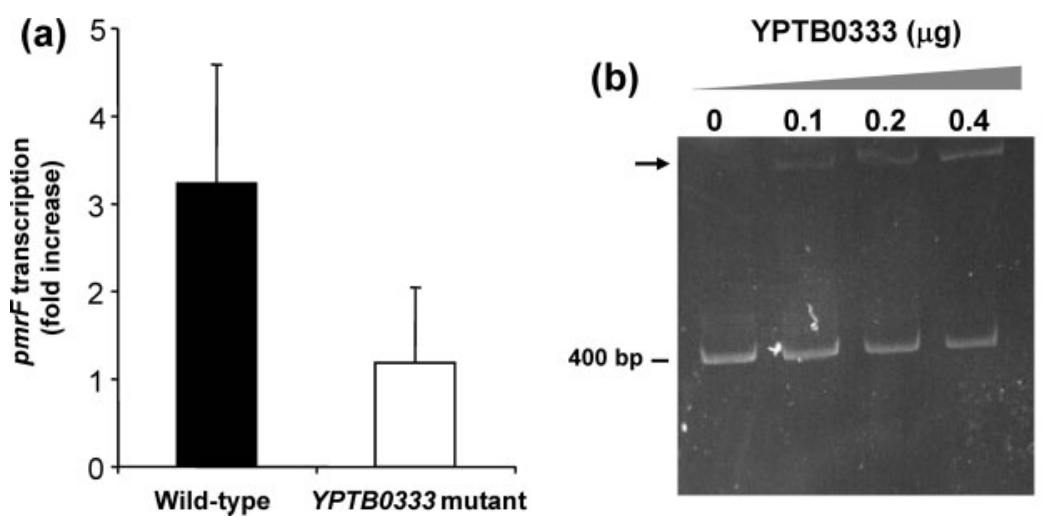

Fig. 6. Regulation of $Y$. pseudotuberculosis pmrF gene expression by YРTВ0333. (a) pmrF expression in iron-starved wild-type and YPTB0333-deficient $Y$. pseudotuberculosis. Total RNA from wild-type and YPTB0333deficient $Y$. pseudotuberculosis cultured in standard or iron-depleted LB broth was extracted and reverse-transcribed into pmrFspecific cDNA with primer R11. Next, the cDNA was amplified using real-time PCR (primers F11/R11). The data were normalized against the $16 \mathrm{~S} r \mathrm{rn}$ values obtained with primers $\mathrm{F} 10$ and R10. Results are presented as the fold increase in gene expression under iron-restriction conditions versus standard conditions. Each bar represents the mean value $(+S D)$ of three independent experiments. A Mann-Whitney test was used to compare the two strains in terms of pmrF expression. (b) YPTВ0333 binding to the promoter region of the $Y$. pseudotuberculosis pmrF operon. A 400 bp fragment encompassing the putative $p m r F$ promoter region was PCR-generated with primers F15/R15. The figure shows the electrophoretic mobility of the ethidium bromide-stained $400 \mathrm{bp}$ fragment alone or mixed with $0.1,0.2$ or $0.4 \mu \mathrm{g}$ purified YРТВ0333. The arrow indicates the highestmolecular-mass YPTB0333-His-DNA complex. An excess of the irrelevant DNA fragment did not inhibit YРТВ0з33 binding to the $p m r F$ promoter (data not shown). 
(a)

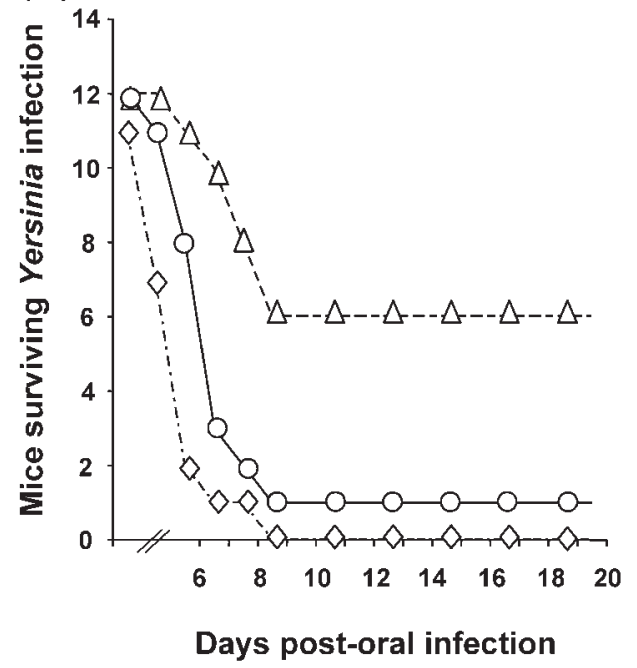

Wild-type $\triangle$ YPTB0333 mutant (b)

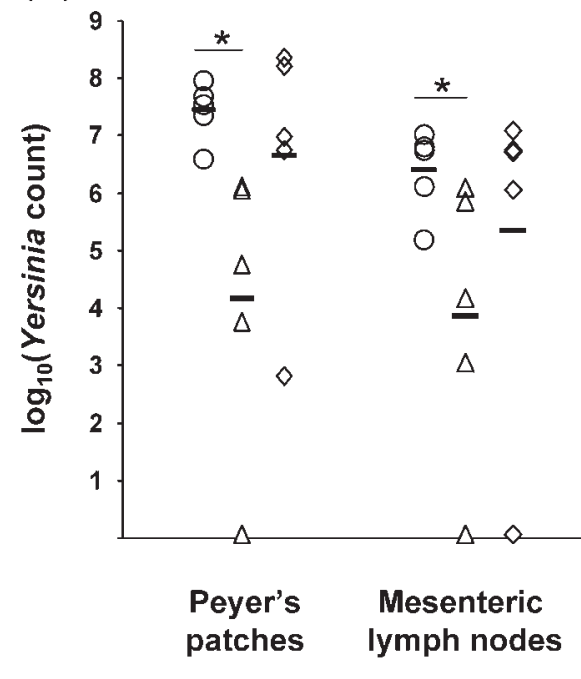

$\diamond$ YPTB0331-0332 mutant

Fig. 7. Oral virulence in the mouse of YPTВ0331-0332 and YPTВ033з Y. pseudotuberculosis mutants. BALB/c mice were fed with $5 \times 10^{8}$ Yersinia. (a) The survival kinetics and survival rate for 12 individuals infected by either the wild-type or the mutant strain are depicted and were compared statistically using the logrank test. (b) Bacterial colonization of Peyer's patches and mesenteric lymph nodes at day 3 post-inoculation. Individual bacterial counts are shown (bars represent the mean value) and were compared using the Mann-Whitney test. $P$ values $<0.05$ are indicated by asterisks.

intravenously (data not shown). The decreased oral virulence of the YPTB0333 mutant was due to its lower ability to colonize the Peyer's patches and the mesenteric lymph nodes at an early stage of gut infection, since 1000fold fewer bacteria were recovered from intestinal lymphoid tissues (Fig. 7b). Taken together, our results indicate that the YPTB0333 gene product is a $Y$. pseudotuberculosis virulence factor.

\section{DISCUSSION}

It has been known for a decade that the two human pathogenic species $Y$. pseudotuberculosis and Y. enterocolitica have differential susceptibility to bactericidal polycationic peptides, with the latter being more susceptible (Bengoechea et al., 1998). However, the genetic differences supporting this phenotypic feature have remained obscure. In the present study, we describe a previously uncharacterized $Y$. pseudotuberculosis chromosomal locus contain- ing two potential effector genes (along with their cognate transcriptional regulatory gene) and show that this locus is involved in polymyxin B resistance. It also contributes to resistance to $\alpha$-helical antimicrobial peptides and polyphemusin. Transfer of this locus into $Y$. enterocolitica rendered this bacterium significantly more resistant to the action of polymyxin $B$.

In line with this observation, an inter-species genomic comparison revealed that YPTB0331 and YPTB0332 are present (but strongly altered) in Y. enterocolitica. In the O8 serogroup strain 8081 sequenced genome (Thomson et al., 2006), Ye0314 (the YPTB0332 counterpart) is intact but Ye0313 (the YPTB0331 counterpart) is truncated at its 5' end. Furthermore, no potential YPTB0333 orthologue has been detected. Identical results were observed in PCR assays (using primers defined from the strain 8081 genomic sequence) carried out on a broad range of $Y$. enterocolitica representatives, including the IP383 (O9 serogroup) strain used in this study (data not shown). In silico analysis of the

Table 4. Susceptibility of $Y$. pseudotuberculosis YРТВ0333 mutant to six antimicrobial peptides

\begin{tabular}{|lrrccccc|}
\hline Strain & \multicolumn{5}{c|}{ MIC $\left(\boldsymbol{\mu g ~ \mathbf { ~ m } ^ { - 1 } )}\right.$} \\
\cline { 2 - 7 } & CP26 & CP29 & LL-37 & Polyphemusin & Bac2A & Indolicidin \\
\hline Wild-type & $>512$ & 64 & 64 & 8 & $>512$ & 16 \\
YPTB0333 mutant & 64 & 2 & 32 & 1 & $>512$ & 16 \\
\hline
\end{tabular}


Ye0313 promoter region also revealed that its sequence differs from that of YPTB0331, raising the possibility that $Y e 0313$ and Ye0314 are not transcribed at all; the fact that the complete $Y$. pseudotuberculosis locus (instead of YPTB0333 alone) is required to give $Y$. enterocolitica strain IP383 a polymyxin B-resistance level similar to that observed in Y. pseudotuberculosis is consistent with this hypothesis.

Polymyxin B resistance in Y. pseudotuberculosis can be mediated by the $p m r F$ operon (Marceau et al., 2004). This polycistronic unit comprises seven genes ( $p$ mrHFIJKLM) required for the substitution of lipid A with L-4aminoarabinose (Gunn et al., 1998). The products of the pmrH, $-F,-I,-J$ and $K$ genes catalyse the biosynthesis and attachment of this cationic sugar to the lipid A of LPS. The pmrL and pmrM products belong to the drug/metabolite exporter family and have been recently shown to form a heterodimer that transfers the L-4-aminoarabinose linked to the undecaprenyl phosphate of the lipid from the cytoplasmic to the periplasmic side of the inner membrane. In E. coli, pmrL and pmrM inactivation is not enough to abolish L-4-aminoarabinose export to the periplasm (Yan et al., 2007); additional, unidentified drug/metabolite exporters may thus exist. YРTB0331 is predicted to contain 10 membrane-spanning peptide segments and transporterspecific motifs, and thus falls into the MFS, which contains members capable of exporting molecules of various sizes through the inner membrane (Pao et al., 1998). This raises the possibility that YPTB0331 participates in the pmrF operon-driven polymyxin B-resistance mechanism as an accessory L-4-aminoarabinose exporter. In Y. pseudotuberculosis, both pmrF and YPTB0331/2 operons are regulated by YPTB0333 in a coordinated manner, suggesting that the mechanisms driven by these two distant gene sets may be closely associated in the performance of a common physiological function. However, as we previously reported (Marceau et al., 2004), the former operon is essential for polymyxin B resistance in $Y$. pseudotuberculosis, whereas the latter (as shown in this study) appears to be dispensable. This observation suggests that, in this species, the genetic information supplied by YPTB0331 and YPTB0332 is redundant, due to the existence of either paralogues or genes that rescue the resistance process in other ways. In contrast, this situation was not observed in $Y$. enterocolitica: $p m r F$-dependent resistance to antimicrobial peptides absolutely required YPTB0331 and YPTB0332, and the consequences of the $p m r F$ inactivation were detectable after trans-complementation with the complete locus but not with the regulatory gene YPTB0333 alone (data not shown). In addition, our preliminary results revealed that $p m r F$ transcription levels are similar (and PhoP-PhoQ dependent) in both species under the conditions tested here. Taken as a whole, these data rule out the hypothesis of less efficient transcription of the pmrF operon in $Y$. enterocolitica, but raise the possibility that products of the pmrF operon and those of YPTB0331 and YPTB0332 participate in a common antimicrobial resistance process. In Y. enterocolitica, PmrL- and PmrMlike proteins are less than $80 \%$ identical to their respective $Y$. pseudotuberculosis counterparts and thus may be less efficient in the former species. This is consistent with the possibility that YРTB0331 and YРTB0332 are involved in a supplementary means of L-4-aminoarabinose export through the inner membrane.

Resistance mechanisms to antimicrobial peptides are often activated in response to potentially membrane-damaging environmental conditions, such as abnormal $\mathrm{pH}$, temperature and metal ion concentrations. The effects of $\mathrm{Mg}^{2+}$ scarcity on regulation of polymyxin B resistance pathways have been extensively studied, especially in Salmonella enterica. More recently, it has been reported that an excess of $\mathrm{Fe}^{3+}$ is associated with greater antimicrobial resistance in this bacterial model (Wösten et al., 2000). Like the process induced by $\mathrm{Mg}^{2+}$ deprivation, the high-iron-induced polymyxin $\mathrm{B}$ resistance process has been shown to require the pmrF operon (Gunn et al., 1998), and to involve complex and partially overlapping regulatory mechanisms. Here, for the first time to our knowledge, we provide evidence to suggest that low iron levels also trigger pmrFmediated bacterial resistance to antimicrobial peptides. The fact that the genetic locus in question is absent or only partially present in sequenced bacterial genomes (including Salmonella) suggests that this mechanism is available in only a limited number of $p m r F$ operon-harbouring species.

Based on the presence of a helix-turn-helix motif and a typical substrate-binding domain, YPTB0333 can be classified within the LysR transcriptional regulator family, along with the family prototype (YPTB3046), RovM (YPTB2588) and 17 other putative regulators detected in the $Y$. pseudotuberculosis strain IP2953 genome. The most similar homologous protein (found in another enterobacterial species, Citrobacter koseri) displays only $50 \%$ identity with YPTB0333, suggesting that this regulator is at least specific to yersiniae if not unique to Y. pseudotuberculosis and its derivative species Yersinia pestis. According to our data, the activity of YРTB0333 depends strongly on iron levels. Amino acid sequence analysis of the putative YPTB0333 substrate-binding domain revealed a particular ExxE motif that is also present in several iron-binding eukaryotic proteins and thought to be involved in iron recognition in PmrB, the sensor of the bacterial twocomponent system PmrA-PmrB (Wösten et al., 2000). This finding, combined with the fact that YРTB0333 transcription and autoregulation depend on iron, raises the hypothesis of a direct interaction between this regulator and the metal in question (which, in such a situation, would behave as an anti-inducer). YРTB0333 is able (at least indirectly) to positively regulate $y f e$ operon transcription, whereas Fur represses this polycistronic unit. This observation indicates that these two regulators have overlapping spheres of influence (at least in this respect) and that YPTB0333 might function as a Fur antagonist. Experiments seeking to demonstrate such a property are currently in progress. 
YPTB0333 controls the transcription level of four separate loci that mediate at least two apparently distinct physiological processes (i.e. iron uptake and resistance to antimicrobial peptides), and hence may be considered to be a pleiotropic regulator. The RSAT DNA-pattern tool (http://rsat.bigre.ulb.ac.be/rsat/) predicted a consensus DNA-binding motif (CCAkGAAGGy) by alignment with YPTB0333-targeted promoters. A search for this motif within the Y. pseudotuberculosis IP2953 genome sequence revealed the existence of at least eight other genes (two of which are absent in the $Y$. enterocolitica genome) putatively controlled by YPTB0333 (see Supplementary Table S1). A comparative transcriptome analysis of the wild-type and the YPTB0333 mutant might provide more information on this point.

Since inactivation of YPTB0333 attenuates bacterial colonization in mice infected by the oral route, it is also a virulence factor; however, YPTB0333 is not required for bacterial systemic infection. This finding might be related to differences in gut and blood antimicrobial peptide contents. Indeed, cryptdins are secreted in large amounts in the intestinal lumen of mice (Ayabe et al., 2000), whereas these defensins are not produced by murine polymorphonuclear leukocytes (Eisenhauer \& Lehrer, 1992), phagocytes which are essential for host defence against Y. pseudotuberculosis. As we previously reported (Marceau et al., 2004), the Y. pseudotuberculosis pmrF operon is dispensable for mouse infection and, consistently, the results presented here show that YPTB0331 and YPTB0332 are also not necessary. A contribution of the YPTB0333regulated $y f e$ operon [required for deep organ colonization by $Y$. pestis (Bearden et al., 1998)] to systemic infection can also be ruled out, since the YPTB0333 mutant is as virulent as the wild-type after an intravenous challenge; however, involvement of $y f e$ in oral infection is still an open question. It now remains to identify virulence genes belonging to the YPTB0333 regulon.

\section{ACKNOWLEDGEMENTS}

S. A. received a postgraduate fellowship from the Ministère de l'Enseignement Supérieur et de la Recherche and the Fondation pour la Recherche Médicale. R.E.W.H. is funded by the Advanced Foods and Materials Network and Canadian Institutes for Health Research, and is the recipient of a Canada Research Chair. We thank J. Herrou, I. Ricard and C. Laurans for technical assistance, and C. Carnoy, M. Chamaillard, F. Sebbane and J. C. Sirard for helpful discussions.

\section{REFERENCES}

Andrews, S. C., Robinson, A. K. \& Rodriguez-Quinones, F. (2003). Bacterial iron homeostasis. FEMS Microbiol Rev 27, 215-237.

Ayabe, T., Satchell, D. P., Wilson, C. L., Parks, W. C., Selsted, M. E. \& Ouellette, A. J. (2000). Secretion of microbicidal $\alpha$-defensins by intestinal Paneth cells in response to bacteria. Nat Immunol 1, 113118.

Bagg, A. \& Neilands, J. B. (1987). Ferric uptake regulation protein acts as a repressor, employing iron (II) as a cofactor to bind the operator of an iron transport operon in Escherichia coli. Biochemistry 26, 5471-5477.

Bearden, S. W., Staggs, T. M. \& Perry, R. D. (1998). An ABC transporter system of Yersinia pestis allows utilization of chelated iron by Escherichia coli SAB11. J Bacteriol 180, 1135-1147.

Bengoechea, J. A., Lindner, B., Seydel, U., Diaz, R. \& Moriyon, I. (1998). Yersinia pseudotuberculosis and Yersinia pestis are more resistant to bactericidal cationic peptides than Yersinia enterocolitica. Microbiology 144, 1509-1515.

Bevins, C. L. (2004). The Paneth cell and the innate immune response. Curr Opin Gastroenterol 20, 572-580.

Bottone, E. J. (1997). Yersinia enterocolitica: the charisma continues. Clin Microbiol Rev 10, 257-276.

Calderwood, S. B. \& Mekalanos, J. J. (1987). Iron regulation of Shiga-like toxin expression in Escherichia coli is mediated by the fur locus. J Bacteriol 169, 4759-4764.

Carnoy, C., Mullet, C., Muller-Alouf, H., Leteurtre, E. \& Simonet, M. (2000). Superantigen YPMa exacerbates the virulence of Yersinia pseudotuberculosis in mice. Infect Immun 68, 2553-2559.

Chain, P. S., Carniel, E., Larimer, F. W., Lamerdin, J., Stoutland, P. O., Regala, W. M., Georgescu, A. M., Vergez, L. M., Land, M. L. \& other authors (2004). Insights into the evolution of Yersinia pestis through whole-genome comparison with Yersinia pseudotuberculosis. Proc Natl Acad Sci U S A 101, 13826-13831.

Conchas, R. F. \& Carniel, E. (1990). A highly efficient electroporation system for transformation of Yersinia. Gene 87, 133-137.

Donnenberg, M. S. \& Kaper, J. B. (1991). Construction of an eae deletion mutant of enteropathogenic Escherichia coli by using a positive-selection suicide vector. Infect Immun 59, 4310-4317.

Eisenhauer, P. B. \& Lehrer, R. I. (1992). Mouse neutrophils lack defensins. Infect Immun 60, 3446-3447.

Flamez, C., Ricard, I., Arafah, S., Simonet, M. \& Marceau, M. (2008). Phenotypic analysis of Yersinia pseudotuberculosis 32777 response regulator mutants: new insights into two-component system regulon plasticity in bacteria. Int J Med Microbiol 298, 193-207.

Foultier, B., Troisfontaines, P., Muller, S., Opperdoes, F. R. \& Cornelis, G. R. (2002). Characterization of the $y$ sa pathogenicity locus in the chromosome of Yersinia enterocolitica and phylogeny analysis of type III secretion systems. J Mol Evol 55, 37-51.

Friedrich, C., Scott, M. G., Karunaratne, N., Yan, H. \& Hancock, R. E. (1999). Salt-resistant alpha-helical cationic antimicrobial peptides. Antimicrob Agents Chemother 43, 1542-1548.

Friedrich, C. L., Moyles, D., Beveridge, T. J. \& Hancock, R. E. (2000). Antibacterial action of structurally diverse cationic peptides on Grampositive bacteria. Antimicrob Agents Chemother 44, 2086-2092.

Garcia Vescovi, E., Soncini, F. C. \& Groisman, E. A. (1996). $\mathrm{Mg}^{2+}$ as an extracellular signal: environmental regulation of Salmonella virulence. Cell 84, 165-174.

Groisman, E. A., Kayser, J. \& Soncini, F. C. (1997). Regulation of polymyxin resistance and adaptation to low $-\mathrm{Mg}^{2+}$ environments. J Bacteriol 179, 7040-7045.

Gudmundsson, G. H., Agerberth, B., Odeberg, J., Bergman, T., Olsson, B. \& Salcedo, R. (1996). The human gene FALL39 and processing of the cathelin precursor to the antibacterial peptide LL-37 in granulocytes. Eur J Biochem 238, 325-332.

Gunn, J. S., Lim, K. B., Krueger, J., Kim, K., Guo, L., Hackett, M. \& Miller, S. I. (1998). PmrA-PmrB-regulated genes necessary for 4aminoarabinose lipid A modification and polymyxin resistance. $\mathrm{Mol}$ Microbiol 27, 1171-1182.

Gunn, J. S., Ryan, S. S., Van Velkinburgh, J. C., Ernst, R. K. \& Miller, S. I. (2000). Genetic and functional analysis of a PmrA-PmrB-regulated 
locus necessary for lipopolysaccharide modification, antimicrobial peptide resistance, and oral virulence of Salmonella enterica serovar Typhimurium. Infect Immun 68, 6139-6146.

Hancock, R. E. \& Diamond, G. (2000). The role of cationic antimicrobial peptides in innate host defences. Trends Microbiol 8, 402-410.

Hentze, M. W., Muckenthaler, M. U. \& Andrews, N. C. (2004). Balancing acts: molecular control of mammalian iron metabolism. Cell 117, 285-297.

Heroven, A. K. \& Dersch, P. (2006). RovM, a novel LysR-type regulator of the virulence activator gene rovA, controls cell invasion, virulence and motility of Yersinia pseudotuberculosis. Mol Microbiol 62, 1469-1483.

Heroven, A. K., Bohme, K., Tran-Winkler, H. \& Dersch, P. (2007). Regulatory elements implicated in the environmental control of invasin expression in enteropathogenic Yersinia. Adv Exp Med Biol 603, 156-166.

Jin, T., Bokarewa, M., Foster, T., Mitchell, J., Higgins, J. \& Tarkowski, A. (2004). Staphylococcus aureus resists human defensins by production of staphylokinase, a novel bacterial evasion mechanism. J Immunol 172, 1169-1176.

Leong, D. \& Murphy, J. R. (1985). Characterization of the diphtheria tox transcript in Corynebacterium diphtheriae and Escherichia coli. J Bacteriol 163, 1114-1119.

Lory, S. (1986). Effect of iron on accumulation of exotoxin A-specific mRNA in Pseudomonas aeruginosa. J Bacteriol 168, 1451-1456.

Maddocks, S. E. \& Oyston, P. C. (2008). Structure and function of the LysR-type transcriptional regulator (LTTR) family proteins. Microbiology 154, 3609-3623.

Marceau, M., Sebbane, F., Ewann, F., Collyn, F., Lindner, B., Campos, M. A., Bengoechea, J. A. \& Simonet, M. (2004). The $p m r F$ polymyxinresistance operon of Yersinia pseudotuberculosis is upregulated by the PhoP-PhoQ two-component system but not by PmrA-PmrB, and is not required for virulence. Microbiology 150, 3947-3957.

Miller, V. L. \& Mekalanos, J. J. (1988). A novel suicide vector and its use in construction of insertion mutations: osmoregulation of outer membrane proteins and virulence determinants in Vibrio cholerae requires toxR. J Bacteriol 170, 2575-2583.

Miyata, T., Tokunaga, F., Yoneya, T., Yoshikawa, K., Iwanaga, S., Niwa, M., Takao, T. \& Shimonishi, Y. (1989). Antimicrobial peptides, isolated from horseshoe crab hemocytes, tachyplesin II, and polyphemusins I and II: chemical structures and biological activity. J Biochem 106, 663-668.

Moore, R. A., Bates, N. C. \& Hancock, R. E. (1986). Interaction of polycationic antibiotics with Pseudomonas aeruginosa lipopolysaccharide and lipid A studied by using dansyl-polymyxin. Antimicrob Agents Chemother 29, 496-500.

Nizet, V. (2006). Antimicrobial peptide resistance mechanisms of human bacterial pathogens. Curr Issues Mol Biol 8, 11-26.

Pao, S. S., Paulsen, I. T. \& Saier, M. H., Jr (1998). Major facilitator superfamily. Microbiol Mol Biol Rev 62, 1-34.
Ratledge, C. \& Dover, L. G. (2000). Iron metabolism in pathogenic bacteria. Annu Rev Microbiol 54, 881-941.

Sambrook, J. \& Russell, D. W. (2001). Molecular Cloning: a Laboratory Manual, 3rd edn. Cold Spring Harbor, NY: Cold Spring Harbor Laboratory.

Schell, M. A. (1993). Molecular biology of the LysR family of transcriptional regulators. Annu Rev Microbiol 47, 597-626.

Schindler, M. \& Osborn, M. J. (1979). Interaction of divalent cations and polymyxin B with lipopolysaccharide. Biochemistry 18, 44254430 .

Sebbane, F., Devalckenaere, A., Foulon, J., Carniel, E. \& Simonet, M. (2001). Silencing and reactivation of urease in Yersinia pestis is determined by one $\mathrm{G}$ residue at a specific position in the ureD gene. Infect Immun 69, 170-176.

Selsted, M. E., Novotny, M. J., Morris, W. L., Tang, Y. Q., Smith, W. \& Cullor, J. S. (1992). Indolicidin, a novel bactericidal tridecapeptide amide from neutrophils. J Biol Chem 267, 4292-4295.

Shafer, W. M., Qu, X., Waring, A. J. \& Lehrer, R. I. (1998). Modulation of Neisseria gonorrhoeae susceptibility to vertebrate antibacterial peptides due to a member of the resistance/nodulation/division efflux pump family. Proc Natl Acad Sci U S A 95, 1829-1833.

Shai, Y. (2002). Mode of action of membrane active antimicrobial peptides. Biopolymers 66, 236-248.

Simon, R., Priefer, U. \& Pühler, A. (1983). A broad host range mobilization system for in vivo genetic engineering: transposon mutagenesis in Gram negative bacteria. Biotechnology (N Y) 1, 784791.

Stumpe, S., Schmid, R., Stephens, D. L., Georgiou, G. \& Bakker, E. P. (1998). Identification of OmpT as the protease that hydrolyzes the antimicrobial peptide protamine before it enters growing cells of Escherichia coli. J Bacteriol 180, 4002-4006.

Thomson, N. R., Howard, S., Wren, B. W., Holden, M. T., Crossman, L., Challis, G. L., Churcher, C., Mungall, K., Brooks, K. \& other authors (2006). The complete genome sequence and comparative genome analysis of the high pathogenicity Yersinia enterocolitica strain 8081. PLoS Genet 2, e206.

Vaara, M. \& Viljanen, P. (1985). Binding of polymyxin B nonapeptide to Gram-negative bacteria. Antimicrob Agents Chemother 27, 548-554.

Vartivarian, S. E. \& Cowart, R. E. (1999). Extracellular iron reductases: identification of a new class of enzymes by siderophore-producing microorganisms. Arch Biochem Biophys 364, 75-82.

Wösten, M. M., Kox, L. F., Chamnongpol, S., Soncini, F. C. \& Groisman, E. A. (2000). A signal transduction system that responds to extracellular iron. Cell 103, 113-125.

Yan, A., Guan, Z. \& Raetz, C. R. (2007). An undecaprenyl phosphateaminoarabinose flippase required for polymyxin resistance in Escherichia coli. J Biol Chem 282, 36077-36089.

Yeaman, M. R. \& Yount, N. Y. (2003). Mechanisms of antimicrobial peptide action and resistance. Pharmacol Rev 55, 27-55.

Edited by: J. Cavet 